Available online on 15.10.2020 at http://jddtonline.info
Open Access to Pharmaceutical and Medical Research
unrestricted non-commercial use, provided the original work is properly cited

Open $\odot$ Access

Research Article

\title{
Acute toxicity and central and peripheral analgesic activity of flowers and leaves essential oils of Asteriscus graveolens from South-West Algeria
}

\author{
Benaissa Keddar Youcef*, Megherbi Aicha, Said Mohammed El-Amin, Benyamina Abdelfettah, Toumi \\ Fouzia and Bettayeb Zouaouia \\ Laboratory of Ecodevelopment of Spaces, Faculty of Natural and Life Sciences, University of Djillali-Liabès, DZ-22000 Sidi-Bel-Abbès, Algeria
}

\begin{abstract}
The objective of this study is the evaluation of the central and peripheral analgesic activity of the leaves and flowers Essential Oils (EOs) of Asteriscus graveolens as well as their acute toxicity. The pharmacological tests were performed using an animal model. Acute toxicity was determined by Lorke's method. Central analgesic activity was evaluated by the hot plate test, and peripheral analgesic activity was conducted by the writhing test. The results showed that the EOs of $A$. graveolens from both organs are weakly toxic. For the central analgesic activity, the results revealed that leaf EO have a remarkable antinociceptive effect compared to flowers EO with a maximum latency time of the animals on the hot plate on the order of 22.5 seconds. Finally, the peripheral analgesic activity revealed a maximum inhibition of abdominal writhing of $99 \%$ for flowers EO and $96 \%$ for leaves EO.
\end{abstract}

Keywords: Asteriscus graveolens, analgesic activity, toxicity.

Article Info: Received 12 Aug 2020; $\quad$ Review Completed 21 Sep 2020; $\quad$ Accepted 03 Oct 2020; Available online 15 Oct 2020

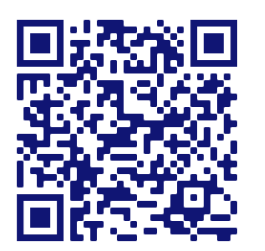

Cite this article as:

Benaissa KY, Megherbi A, Said ME, Benyamina A, Toumi F, Bettayeb Z, Acute toxicity and central and peripheral analgesic activity of flowers and leaves essential oils of Asteriscus graveolens from South-West Algeria, Journal of Drug Delivery and Therapeutics. 2020; 10(5-s):114-118 http://dx.doi.org/10.22270/jddt.v10i5-s.4350

Benaissa Keddar Youcef, Laboratory of Ecodevelopment of Spaces, Faculty of Natural and Life Sciences, University of Djillali-Liabès, DZ-22000 Sidi-Bel-Abbès, Algeria

\section{INTRODUCTION:}

A. graveolens is a species of the family Asteraceae, [synonyms: Bubonium graveolens (Forsk.); Bubonium odorum (Schousb.); Asteriscus cavanillesi (Caball. ); Asteriscus paui; Asteriscus stenophyllus (Link.); Asteriscus stenophyllus; Odontospermum graveolens; Odontospermum odorum (Schoub.); Nauplius graveolens (Forsk.); Buphthalmum odorum (Schoub.)]. 1. This plant family is known for its use as a remedy in traditional medicine 2,3 . A. graveolens is known under the vernacular name "Taffs" and is one of the endemic medicinal plants, widely used by the local population in south-western Algeria 4. It is used to treat various ailments such as fever, gastrointestinal diseases, headache, bronchitis and also as an anti-inflammatory ${ }^{5}$. The aerial part (flowers and leaves) is rich in EO and is especially characterized by a high content of oxygenated terpene compounds such as Chrysanthenyl acetate and Oxocyclonerolidol, which are described in other Asteriscus species, and can be considered chemo-taxonomically as markers of the genus 6,7 . Following our literature search, the literature on the study of the biological activity of this plant is limited to 9 articles, 3 of which deal with its antibacterial activity $8-10$. Other articles by Alilou et al. and Znini et al. showed a considerable antifungal effect 11,12 . Another study was carried out by Znini et al. on the effect of EO from A. graveolens leaves on corrosion inhibition ${ }^{13}$. For the last three articles, studies have been carried out on the antioxidant activity and hemolytic effect of the plant extracts ${ }^{14}$, the antioxidant, antibacterial, antifungal and anticancer activity of EO 15 and finally a final study that confirms the antioxidant and antibacterial power of the plant 16. On the other hand, we have not found any literature dealing with the analgesic activity of this plant, which is why we have taken the initiative to test these essential oils to evaluate central and peripheral analgesia in an animal model.

\section{MATERIALS AND METHODS:}

Extraction of essential oils: the species was harvested during the flowering period in specific locations in SouthWest Algeria. The harvested plant material is dried in a place sheltered from the sun's rays at room temperature and regularly turned over. The aerial part (leaves and flowers) of the plant is roughly cut before the extraction of the EOs by hydro-distillation using a Clevenger apparatus. 
Description of the animal model: The acute toxicity tests and the central and peripheral analgesic study were carried out on mice (BALB/C), from the breeding of the Laboratory of Ecodevelopment of Spaces, Faculty of Natural and Life Sciences, University Djilali Liabes-Sidi Bel Abbès (Algeria). The mice of both sexes are aged between 05 and 06 months and weigh between 30 and $40 \mathrm{~g}$, they are grouped in batches of 05 mice per cage and the females are non-pregnant. They are deprived of food 18 hours before and 03 hours after administration of the product.

Preparation of the products: The essential oils are administered intra-peritoneal (IP) 17. The products for animal treatment have been prepared in suspension in physiological water $(\mathrm{NaCl} 0.9 \%)$ and a few drops of tween 80 , the volume of administration by this route is $10 \mathrm{~mL} / \mathrm{Kg}$ of the animal's body weight as recommended by the American Association for laboratory animal science ${ }^{18}$.
Acute toxicity test: The toxicity of our oils has been determined according to the approach described by Lorke in 1983. 19 The first step is the determination of the approximate extent of toxicity. This was obtained by forming three batches of three mice with each batch receiving by IP route doses of $10,100,1000 \mathrm{mg} / \mathrm{Kg}$ of body weight respectively. The animals were observed during the two hours following the administration of the EOs in order to note all the symptoms of toxicity. The number of deaths was noted after 24 hours and this will be used to complete the next stage of the test. The second part consists of administering specific doses based on the results of the first step (table 1) using only one animal per group and the mortalities are noted after $24 \mathrm{H}$, the test is completed by determining the lethal dose for $50 \%$ of the animals (LD50) by calculating the geometric mean between the non-lethal dose $(0 / 1)$ and the next lethal dose $(1 / 1)$ as shown in the following table (table 1).

Table 1: Number of mortalities in the first step and corresponding doses for the second step ${ }^{19}$.

\begin{tabular}{|c|c|c|c|c|c|c|}
\hline \multicolumn{3}{|c|}{$\begin{array}{l}\text { doses in } \mathrm{mg} / \mathrm{kg} \text { body weight with all } \\
\text { possible results of the first test step }\end{array}$} & \multicolumn{4}{|c|}{$\begin{array}{l}\text { doses chosen for the second step of the test } \\
\text { based on the results of the first step }\end{array}$} \\
\hline 10 & 100 & 1000 & & & & \\
\hline $0 / 3^{*}$ & $0 / 3$ & $0 / 3$ & I & 1600 & 2900 & 5000 \\
\hline $0 / 3$ & $0 / 3$ & $1 / 3$ & 600 & 1000 & 1600 & 2900 \\
\hline $0 / 3$ & $0 / 3$ & $2 / 3$ & 200 & 400 & 800 & 1600 \\
\hline $0 / 3$ & $0 / 3$ & $3 / 3$ & 140 & 225 & 370 & 600 \\
\hline $0 / 3$ & $1 / 3$ & $3 / 3$ & 50 & 100 & 200 & 400 \\
\hline $0 / 3$ & $2 / 3$ & $3 / 3$ & 20 & 40 & 80 & 160 \\
\hline $0 / 3$ & $3 / 3$ & $3 / 3$ & 15 & 25 & 40 & 60 \\
\hline $1 / 3$ & $3 / 3$ & $3 / 3$ & 5 & 10 & 20 & 40 \\
\hline $2 / 3$ & $3 / 3$ & $3 / 3$ & 2 & 4 & 8 & 16 \\
\hline $3 / 3$ & $3 / 3$ & $3 / 3$ & 1 & 2 & 4 & 8 \\
\hline
\end{tabular}

*Number of dead animals/number of animals used

\section{Central analgesic activity:}

It is described in scientific articles as an anti-nociceptive activity. The methods described for testing this activity in mice use a thermal stimulus to trigger a painful reaction, the hot plate test 20 , a technique for estimating the effects of test substances on the threshold of pain sensitivity, based on the principle of placing the animals on a hot surface. The animals will demonstrate the aversive effects of stimulation by first licking their paws and then attempting to escape by jumping. Substances that alter the nociceptive threshold, increase the latency time for licking/jumping (analgesic effect) or decrease it (hyperalgesic effect). The animals were subjected to a pre-test on the hot plate maintained at $55 \pm 1^{\circ} \mathrm{C}$. Animals with a latency time of more than 15 seconds on the hot plate during the pre-test were eliminated. Then the animals were randomized in groups of five, group 1 was treated with saline solution, group 2 with Tramadol ( $30 \mathrm{mg} / \mathrm{Kg}$ ) by IP (central analgesic), and groups 3, 4 and 5 were treated (IP) with $50,100,150 \mathrm{mg} / \mathrm{Kg}$ of EOs from the leaves and flowers of the plant respectively. After 30 minutes of treatment, the animals were placed on the hot plate and the latency time was measured in seconds. The latency time is defined as the length of time the mouse remains on the plate without licking its hind legs or jumping 21.

\section{Peripheral analgesic activity:}

This activity occurs by inducing pain in the ventral region of the animal. It is evaluated by injecting an irritating chemical agent (acetic acid or phenyl benzoquinone) into the peritoneal cavity and results in abdominal contractions, contortions and stretching of the animal's hind legs, hence the name "Writhing test". Groups of five mice were formed. Group 1 (control) received saline by IP route. The second group received the standard drug Diclofenac sodium (10 $\mathrm{mg} / \mathrm{Kg}$, IP) (non-steroidal anti-inflammatory drug) and groups 3, 4 and 5 were treated with doses of 50, 100, 150 $\mathrm{mg} / \mathrm{Kg}$ of EO from both plant organs respectively.

After 30 minutes, the animals were given a $1 \%$ acetic acid solution by IP. The number of abdominal contractions (contortion) was counted after 05 minutes of the 10-minute injection of acetic acid. The analgesic effect was evaluated according to the following formula 21.

$\%$ Inhibition $=[(A-B) / A] \times 100$ 
A: The average number of contortions of the mice in the control batch.

B: The average number of contortions of the mice in the treated batch.

\section{RESULTS:}

Acute toxicity: The results of the first step of the Lorke's test which determines the approximate extent of toxicity after the doses of $10 \mathrm{mg} / \mathrm{Kg}, 100 \mathrm{mg} / \mathrm{Kg}, 1000 \mathrm{mg} / \mathrm{Kg}$ are presented in the following table (Table 2).

Table 2: Number of deaths according to the doses of extracts of essential oils from the flowers and leaves of A. graveolens.

\begin{tabular}{|c|c|c|c|}
\cline { 2 - 4 } \multicolumn{1}{c|}{} & \multicolumn{3}{c|}{ Step 1 } \\
\hline Dose (mg/Kg) & 10 & 100 & 1000 \\
\hline \multicolumn{3}{|c|}{ Number of deaths after 24 hours } \\
\hline Leaves & $0 / 3$ & $0 / 3$ & $1 / 3$ \\
\hline Flowers & $0 / 3$ & $0 / 3$ & $1 / 3$ \\
\hline
\end{tabular}

IP administration of EOs from the leaves and flowers of $A$. graveolens at doses of 10 and $100 \mathrm{mg} / \mathrm{Kg}$ did not cause any abnormal behavior and no animal mortality after $24 \mathrm{H}$, which means that these two doses are not toxic for mice. On the other hand, administration of the $1000 \mathrm{mg} / \mathrm{Kg}$ dose induced a change in behavior and the appearance of some signs of toxicity after about $15 \mathrm{~min}$ of the injection. At first, hyperactivity, abdominal contortions and irritation were observed, then sedation was noticed; the mobility of the animals gradually decreased to the point of an inability to move. Other symptoms were observed after almost $18 \mathrm{H}$; malaise, anorexia (loss or decrease in appetite) and tachycardia (increase in heart rate). One animal out of three had a lowered heart rate (bradycardia) and eventually died after about 24 hours. The survivors resumed their normal behavior and all symptoms disappeared after 48 hours.

From the first phase of the test we were able to determine the doses to be administered in the second phase thanks to the table drawn up by Lorke (table 1 materials and methods). The results of the second stage are presented in the following table (table 3).

Table 3: Results of the second step of the Lorke test.

\begin{tabular}{|c|l|c|c|c|c|}
\hline & \multicolumn{5}{|c|}{ Step 2 } \\
\cline { 1 - 4 } Dose (mg/Kg) & 600 & 1000 & 1600 & 2900 & \\
\hline \multicolumn{7}{|c|}{ Number of deaths after 24 hours } & DL50 (mg/Kg) \\
\hline Leaves & $0 / 1$ & $1 / 1$ & $1 / 1$ & $1 / 1$ & 174,60 \\
\hline Flowers & $0 / 1$ & $0 / 1$ & $1 / 1$ & $1 / 1$ & 1264,91 \\
\hline
\end{tabular}

The results of the second stage reveal that the EO of the flowers have a high LD50 value (1264.91) resulting from the calculation of the geometric mean between the dose 1000 and $1600 \mathrm{mg} / \mathrm{Kg}$ compared to the LD50 value of the leaves (774.60) resulting from the calculation of the geometric mean between the dose 600 and $1000 \mathrm{mg} / \mathrm{Kg}$, which shows that the EO of the flowers are less toxic than those of the leaves.

\section{Central analgesic activity:}

The temperature on the hot plate is maintained at $55 \pm 1^{\circ} \mathrm{C}$ to measure the latency time of the animals. The results obtained are presented in the bar graphs below (figure 1).

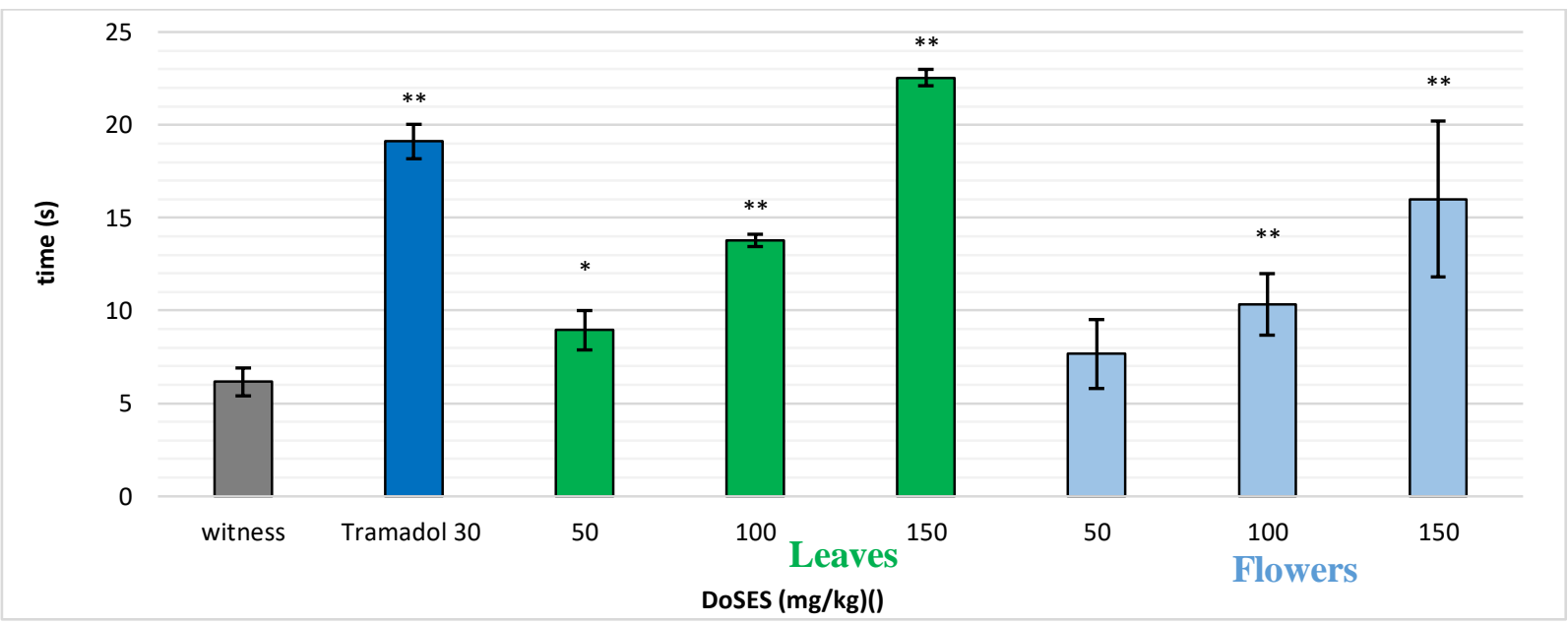

Asterisks indicate statistically significant differences from the control. ${ }^{*} \mathrm{P}<0.05,{ }^{* *} \mathrm{P}<0.001$.

Figure 1: Mouse latency time on the hotplate. 


\section{Peripheral analgesic activity:}

In this test, the IP injection of a $1 \%$ acetic acid solution (chemical stimulus) causes irritations in the peritoneal cavity expressed by pain (the animal presents a twisting phenomenon of its body). The different doses of EOs are injected in order to test their effectiveness in reducing these contortions and thus prevent the phenomenon of torsion to pain. The percentages of inhibitions have been calculated and presented in the bar graphs below (figure 2).

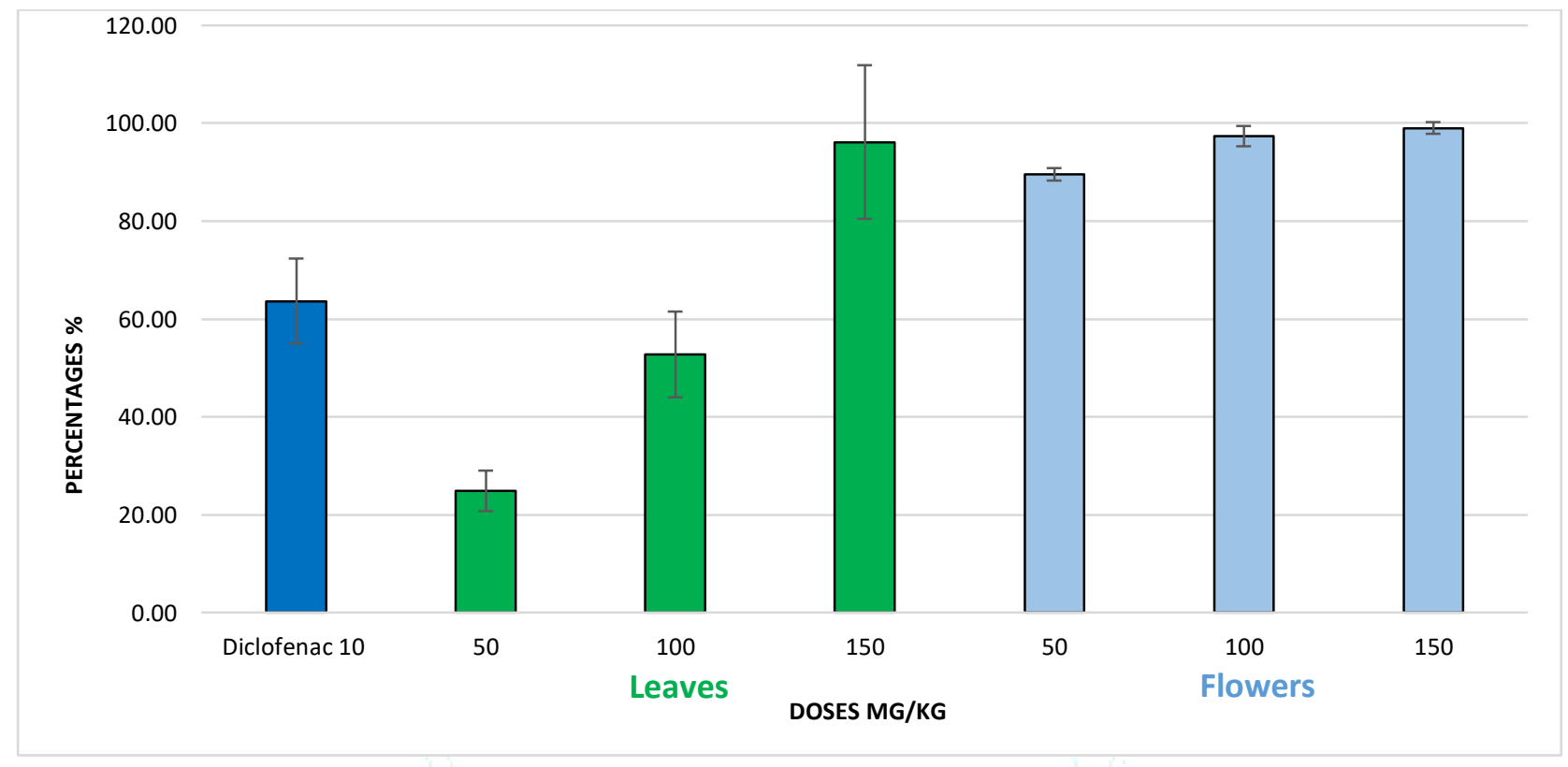

Figure 2: Percentage inhibition of abdominal contortions in mice.

\section{DISCUSSION:}

The study of acute toxicity by IP route shows an LD50 of $774.60 \mathrm{mg} / \mathrm{Kg}$ for the EO of A. graveolens leaves and an LD50 of $1264.91 \mathrm{mg} / \mathrm{Kg}$ for that of flowers, which are relatively high values, indicating a low toxicity of these EOs. According to the toxicity scale established by Hodge and Sterner, the LD50s of our oils are classified at level four, which corresponds to slightly toxic substances 22 . Following our literature search, there are no studies on the toxicity of this plant. Moreover, the duration of observation during our toxicity test allowed us to observe a dose-dependent sedative action ( 30 minutes up to 3 hours after the injection of the EOs). Following these results, we decided to test their central and peripheral analgesic activities.

Pharmacologists classify painkillers into two categories; narcotic or opioid analgesics which act on the central nervous system, and antipyretic analgesics which have a peripheral action and which also usually have antiinflammatory effects 23 .

EOs from the leaves and flowers of A. graveolens increased the latency time of the mice on the hot plate in a dosedependent manner, with the exception of the $50 \mathrm{mg} / \mathrm{Kg}$ dose for both organs, which did not give a significantly different result from the witness. The $100 \mathrm{mg} / \mathrm{Kg}$ dose of both organs showed a slightly higher result than the witness lot but remarkably lower than the Tramadol-treated lot. The effect obtained with the maximum dose of EO from the flowers is close to that of Tramadol, however the latter is much lower than the effect obtained with EO from the leaves. It is therefore noted that the leaves have a remarkable central analgesic effect compared to the flowers.

The increase in the latency time of mice on the hot plate is explained by the inhibition of pain perception which is favored by opioid analgesics such as Tramadol. Tramadol has been used in the central analgesia test as a reference drug by action on mature receptors $(\mu)$ and on the aminergic system, it prevents the reuptake of norepinephrine and serotonin by neurons and its efficacy is comparable to that of codeine and dextropropoxyphene ${ }^{23}$. Regarding the effect of our EOs on the increase of the latency time on the hot plate, the results are in agreement with the ethnobotanical data reported by Ramdane et al. on the traditional therapeutic use of A. graveolens to soothe migraine pain 24 and also with the bibliographical data which illustrate the interest of the plant to soothe headaches and facial neuralgia pain 25 .

With regard to peripheral analgesic activity, the EOs of the flowers inhibited abdominal contortions in a highly significant way compared to the reference treatment (Diclofenac), even at low doses $(50 \mathrm{mg} / \mathrm{Kg})$, and the maximum effect reached $99 \%$ at a dose of $150 \mathrm{mg} / \mathrm{Kg}$. On the other hand, the effect of leaves EO on the inhibition of abdominal contortions is dose-dependent and it reaches its maximum at the dose of $150 \mathrm{mg} / \mathrm{Kg}$, which was higher than that of the reference treatment (Diclofenac). The pain caused by the injection of acetic acid is due to the release of serotonin, histamine, bradykinins and prostaglandins, these chemical mediators stimulate peripheral nociceptive neurons and induce an increase in vascular permeability 26,27. The remarkable effect of our EOs could be linked to the inhibition of the release of these chemical mediators, so they can also be considered as peripheral analgesics that antagonize the inflammatory phase 28,29 , but their mechanism of action remains unknown. In traditional medicine, A. graveolens has been used to alleviate the pain of certain chronic inflammations such as rheumatism ${ }^{24}$ and the fresh leaves of this plant have been used to treat toothache and gum inflammation (gingivitis) 30 .

\section{CONCLUSION:}

The results of acute toxicity tests by intra-peritoneal route seem to indicate that the EOs of the flowers and leaves of $A$. 
graveolens are not toxic at experimental doses (50-100-150 $\mathrm{mg} / \mathrm{Kg}$ ) without excluding a sedative effect on the central nervous system.

The results of the studies of the analgesic activities of the EOs of this species confer a strong peripheral analgesic power from the minimum dose for both organs but clearly for the flowers. Whereas the central analgesic action presents a weak anti-nociceptive power except for the maximum dose of EOs of the leaves which presents an effect superior to the reference treatment.

These results constitute a scientific basis which justifies the traditional use of $A$. graveolens in the treatment of certain pathologies. It would also be judicious to evaluate the psychotropic activity of the plant in view of the sedation recorded during the acute toxicity tests, and also its antiinflammatory power which could accompany the strong peripheral analgesic potential observed. In addition, an indepth study concerning the mechanism of action could be carried out subsequently.

\section{REFERENCES:}

1-Dobignard A, Chatelain C.Index synonymique et bibliographique de la flore d'Afrique du Nord. Switzerland: Edition des Conservatoire et Jardin botaniques de la Ville de Genève; 20102011

2- Said MEA, Vanloot P, Bombarda I, et al," Analysis of the major chiral compounds of Artemisia herba-alba essential oils (EOs) using reconstructed vibrational circular dichroism (VCD) spectra: En route to a VCD chiral signature of Eos" Anal Chim Acta, 2016; 903:121-130.

3-Said MEA, Militello M, Saia S, et al, "Artemisia arborescens Essential Oil Composition, Enantiomeric Distribution, and Antimicrobial Activity from Different Wild Populations from the Mediterranean Area"Chem Biodivers,2016; 13(8):1095-102.

4-Cheriti A, Saad A, Belboukhari N, et al. " The essential oil composition of Bubonium graveolens (Forssk) Maire from the Algerian Sahara" Flavour Fragr, 2007; J 22:286-286.

5-Cristofari G, Znini M, Majidi L, et al, "Chemical diversity of essential oils from Asteriscus graveolens (Forssk) less.: identification of cis-8-Acetyloxychrysanthenyl acetate as a new natural component" Chem Biodivers, 2012; 9:727-738.

6-Said MEA, Bombarda I, Naubron JV, et al, " Isolation of the major chiral compounds from Bubonium graveolens essential oil by HPLC and absolute configuration determination by VCD" Chirality, 2017; 29(2):70-79.

7-Jakupovic J, Lehmann L, Bohlman F, et al, "Nerolidol derivatives from Asteriscus sericeus"Phytochemistry, 1987; 26:2854-2855.

8-Chaib F, Allali H, Bennaceur M, et al, "Chemical Composition and Activity of Essential Oils from the Aerial Parts of Asteriscus graveolens (Forssk) Less.and Pulicaria incisa (Lam) DC.: Two Asteraceae Herbs Growing Wild in the Hoggar" Chem.Biodiversity, 2017; 14:e1700092.

9-Al-Rimawi F, Alakhras F, Al-Zereini W, et al, " HPLC Analysis of Chemical Composition of Selected Jordanian Medicinal Plants and their Bioactive Properties" Oriental Journal of Chemistry, 2018; 34(5):2397-2403.

10-Berbaoui, Cheriti et Ould El Hadj-Khelil, "Antibacterial Effect of Some Asteraceae of Southern Algeria on Nosocomial Strains of the Genus Staphylococcus" Natural Products Chemistry \& Research, 2018 6(1).
11-Alilou H, Akssira M, et al, " Isolement, Identification et activite antifongique de deux sesquiterpenes d'Asteriscus graveolens Subsp.Odorus(Schousb.) Greuter" European Scientific Journal, 2016; 12(33).

12-Znini M, Cristofari G, Majidi L, et al, "Antifungal Activity of Essential Oil from Asteriscus graveolens against Postharvest Phytopathogenic Fungi in Apples"Natural product communications, 2011; 6(11):1763-1768.

13-Znini M, Cristofari G, Majidi L, et al, "Green Approach to Corrosion Inhibition of Mild Steel by Essential Oil Leaves of Asteriscus Graveolens (Forssk.) in Sulphuric Acid Medium" Int J Electrochem Sci, 2012; 3959 - 3981.

14-Haddouchi F, Chaouche TM, Halla N, "Screening phytochimique, activités antioxydantes et pouvoir hémolytique de quatre plantes sahariennes d'Algérie"Phytothérapie, 2016.

15-Aouissi H, Gourine N, Wang H, et al, "Chemical composition, antioxidative, antimicrobial and anti-cancer activities of Asteriscus graveolens (Forssk) essential oil" Oriental Pharmacy and Experimental Medicine, 2018

16-Ramdane F, Essid R, Mkadmini K, et al, "Phytochemical composition and biological activities of Asteriscus graveolens (Forssk) extracts" Process Biochemistry, 2017.

17- Vogel HG, Hock FJ, Maas J, et al. Drug Discovery and Evaluation: Safety and Pharmacokinetic Assays, 1er ed. Berlin; New York: Springer;2006.

18- Turner PV, Brabb T, Pekow C, et al. Administration of Substances to Laboratory Animals: Routes of Administration and Factors to Consider. J Am Assoc Lab Anim Sci JAALAS; 2011; 50:600-613.

19- Lorke D. A new approach to practical acute toxicity testing. Arch Toxicol; 1983. 54:275-287.

20-Eddy NB, Leimbach D, "Synthetic analgesics II. Dithienylbutenyland dithienylbutylamines" J Pharmacol Exp Ther,1953; 107: 385-393.

21- Muhammad N, Saeed M, Khan H, "Antipyretic, analgesic and anti-inflammatory activity of Viola betonicifolia whole plant" BMC Complement. Altern. Med, 2012; 12, 59.

22-Hodge HC, Sterner JH. Tabulation of Toxicity Classes. Am.Ind.Hyg.Assoc.Q; 1949; 10:93-96.

https://doi.org/10.1080/00968204909344159

23-Cohen Y, Jacquot C, Valette G. Pharmacologie.France: Elsevier Masson, Issy-les- Moulineaux ;2008.

24-Ramdane F, Hadj Mahammed M, Didi Ould Hadj M, et al, "Ethnobotanical study of some medicinal plants from Hoggar, Algeria"Medicinal Plants Research, 2015; 9(30):820-827.

25-Quezel P, et Santa C. Nouvelle flore de l'Algérie et des régions désertiques méridionales.Paris :CNRS. 1962-1963; 2:1170.

26-Frederico AV, Higor FL, Elson AC, et al, "Evaluation of the antinociceptive and anti-inflammatory effects of the acetone extract from Anacardium occidentale L" Brazil J Pharmaceut Sci, 2009; 45:437-42.

27-Wantana R, Tassanee N, Subhadhirasakul S, "Antinociceptive, antipyretic, and anti-inflammatory activities of Putranjiva roxburghii Wall. Leaf extract in experimental animals" J Nat Med, 2009; 63:290-6.

28-Gorzalczany S, Marrassini C, Mino J, et al, "Antinociceptive activity of ethanolic extract and isolated compounds of Urtica circu-laris" J Ethnopharmacol, 2011; 134:733-8.

29-Prashant RV, Amit AJ, Vivekanand AC, Alpana JA, "Antinociceptive activity of alcoholic extract of Hemidesmus indicus R. Br. In mice" J Ethnopharmacol, 2005; 102 :298-301.

30- Ghourri M, Zidane L, El Yacoubi H, Rochdi A, Fadli, Douira A, "Etude floristique et ethnobotanique des plantes médicinales de la ville d'El Ouatia (Maroc Saharien)" Journal of Forestry Faculty, 2012; 12(2):218-235. 